\title{
Kardiyoloji Hekimlerinin İskemik Koroner Arter Hastalığının Değerlendirilmesinde Nükleer Tıp Tetkikleri ile İlgili Görüşleri
}

\author{
@ (1D) Dr. Öğr. Üyesi Ahmet Salan¹, @ (1D) Dr. Öğr. Üyesi Ekrem Aksu²
}

${ }^{1}$ Kahramanmaraş Sütçü İmam Üniversitesi Tıp Fakültesi Nükleer Tıp Anabilim Dalı, Kahramanmaraş, Türkiye

${ }^{2}$ Kahramanmaraş Sütçü İmam Üniversitesi Tıp Fakültesi Kardiyoloji Anabilim Dalı, Kahramanmaraş, Türkiye

Öz

Kardiyoloji Hekimlerinin İskemik Koroner Arter Hastalığının Değerlendirilmesinde Nükleer Tıp Tetkikleri ile Ilgili Görüșleri

Amaç: Miyokard perfüzyon sintigrafisinin (MPS) koroner arter hastalığında (KAH) önemli bir yer tutan kullanımı nedeni ile kardiyoloji ve nükleer tıp hekimlerinin daha uyumlu bir çalışma ortamını yakalayabilmeleri için kardiyologların bu alandaki nükleer tıp tetkiklerine bakış açıları ve bunu etkileyen faktörlerin değerlendirilmesi amaçlanmıştır.

Yöntem: 1 Aralık 2019-30 Mart 2020 tarihleri arasında ilimizde 21 kardiyoloji uzmanı ve 5 uzmanlık öğrencisine yönelik 14 sorudan olușan anket çalıșması yapılmışıtır.

Bulgular: Hekimlerin \%90'a yaklaşan oranda iskemik kalp hastalı̆ında özellikle tanı așamasında MPS'ni tercih etmesine rağmen üçte bir civarında hekimin MPS'ne ulaşamadığı saptanmıștır. Nükleer tıp raporlarından genellikle tıbbi anlamda bir memnuniyet mevcuttur. MPS'ne ulașabilen hekimler için nükleer tıp hizmetinin yapısından kaynaklanan tetkik ve randevu süresi ile ilgili olumsuzluklar öne çıkmaktadır. İletişimle ilgili olumlu yaklaşımlar mevcuttur.

Sonuç: ilimizde MPS yüksek doğruluk oranları ile tercih edilen bir tetkiktir. Ancak ulaşılabilirliği kısıtııdır. Bu kısıtlılık nedeni ile uzamış randevu sürelerinin ve olası artmış invaziv girişimlerin getirebileceği kayıpların; MPS’nin daha yaygın kullanımı ile çözülebileceği değerlendirilmektedir. Bu durum özellikle tıp fakültesi içinde gama kamera ihtiyacını değerlendirmeyi öne çıkarmaktadır. Kardiyoloji hekimleriyle karșlıklı karar ve sorumlulukların paylașılmasının yanı sıra iletişim kanallarının artırılması nükleer tıp görüntüleme yöntemlerinin kararlı iskemik KAH tanı ve takibinde kullanım yaygınlığının ve etkinliğinin optimal düzeye çıkmasına katkı sağlayabilir. Anahtar Kelimeler: Nükleer Tıp, Kardiyoloji, Anket, Sintigrafi, İskemik Koroner Arter Hastalığı

\section{Abstract}

Opinions of Cardiology Physicians About Nuclear Medicine Examinations In The Evaluation of Ischemic Coronary Artery Disease

Introduction: Due to the important use of myocardial perfusion scintigraphy (MPS) in coronary artery disease (CAD), cardiology and nuclear medicine physicians work together. So, we aimed to evaluate the perspectives of cardiologists on nuclear medicine examinations and the factors affecting their decisions.

Method: A survey of 14 questions was conducted for 21 cardiology specialists and 5 cardiology assistants in our city between 1 December 2019 and 30 March 2020.

Results: Although nearly $90 \%$ of physicians prefer MPS especially in the diagnosis of ischemic CAD, it was determined that approximately one-third of physicians could not reach MPS in our city. There is generally a medical satisfaction with the nuclear medicine reports. The problems with MPS seem mostly related to appointment time and examination time arising from the nature of the nuclear medicine applications. There are positive approaches to the communication atmosphere.

Conclusion: MPS is a preferred examination with high accuracy rates in our city. However, its accessibility is limited. This limitation and prolonged appointment times may indicate possible health problems and economic losses due to increased invasive procedures. It is considered that it can be solved with wider use of MPS. This situation highlights the need for a gamma camera, especially in the hospital of our medical faculty. In addition to sharing mutual decisions and responsibilities with cardiology physicians, increasing communication channels can contribute to the optimal use of nuclear medicine imaging procedures in the diagnosis and follow-up of stable ischemic CAD.

Keywords: Nuclear Medicine, Cardiology, Survey, Scintigraphy, Ischemic Coronary Artery Disease 


\section{Gíriș}

Miyokard perfüzyon sintigrafisi (MPS) tek foton yayan bilgisayarlı tomografi (SPECT), iskemik koroner arter hastalığının (KAH) tanısında, prognoz belirlenmesinde ve takibinde kullanılmaktadır (1). Bu nedenle, kardiyoloji hekimlerinin iskemik KAH tanı ve takibinde nükleer kardiyoloji seçeneğine yaklaşım tarzının anlaşılması, nükleer tıp tetkiklerine karşı tutumlarının saptanması ve istedikleri tetkiklerden beklentilerinin bilinmesi, uyumlu bir çalıșma ortamına katkı sağlayacaktır (2). Bu çalıșmada ilimizdeki kardiyoloji hekimlerinin günlük pratikte koroner arter hastalığı veya șüphesi olan hastalarda hangi görüntüleme ve/veya laboratuvar tetkiklerini istedikleri ve nükleer tıp tetkiklerine bakıș açısını değerlendirmek amaçlanmıștır.

\section{GEREC VE YÖNTEM}

II sınırları içinde Tıp Fakültesi ve Devlet Hastanelerinde çalışan kardiyologlar ( $n=21)$ ve uzmanlık öğrencilerine $(n=5)$ yönelik olarak 14 adet anket sorusu yöneltildi. Anketler 1 Aralık 2019-30 Mart 2020 tarihleri arasında gerçekleștirildi. Anketlerde sorulardaki her șık için, şıkları ișaretleyen katılımcı sayısı ve katılımcıların yüzdelik kısmı hesaplandı. Kullanılan anket formu Ek 1'de gösterilmiștir.

\section{BULGULAR}

Tüm katılımcılar çalıștıkları hastanede EKG, Eforlu EKG ve biyokimya tetkiklerinin yapılabildiğini belirtirken \%90'ın üzerinde katılımc ise akciğer grafisi ve istirahat ekokardiyografi (EKO) yapılabildiğini bildirmișlerdir. MPS SPECT ve EKG-kapılı (GATED) SPECT birlikte toplamda \%65,4 oranında yapılabilir olarak tanımlanmıștır.

İskemik KAH șüphesi ile gelen stabil tipik/atipik anginalı hastalarda ve bilinen KAH takibinde semptomatik ancak stabil hastalarda istenilen en sık ilk beș tetkik sıralaması aynıdır. Bu iki hasta grubunda ilk iki sırayı olușturan istirahat EKG ve biyokimya tetkikleri aynı oranda tercih edilmiștir (sırasıyla \%96,2 ve \%88,5). Bunları Eforlu EKG, istirahat EKO ve MPS SPECT izlemiștir. Bu sıralamaya uyumlu bir șekilde şüpheli iskemik KAH düșünülen bir hastada test öncesi olasılığın belirlenmesinde ilk iki sırayı "Anamnez + fizik muayene + biyokimya + istirahat EKG" ve "Yaș, cinsiyet ve angina tipi' ile değerlendiririm" seçenekleri almıștır (sırasıyla \%80,8 ve \%73,1). Eforlu EKG seçeneği test öncesi olasılığın belirlenmesinde üçüncü sırada $(\% 65,4)$ MPS ise dördüncü sırada $(\% 53,8)$ yer almıştır. Kardiyoloji hekimlerinin tamamı KAH tanısında stresle tetiklenen iskemi kanıtı için günlük pratikte en çok eforlu EKG'yi kullandıklarını bildirmiștir. Ikinci sırada ise stres MPS SPECT $(\% 61,5)$ gelmektedir. (Stres MPS SPECT ve stres MPS GATED SPECT birlikte: \%65,4 dür). İnvaziv koroner anjiyografi (KAG) \% 15,4 ile üçüncü sırada yer almıştır (Tablo 1).
Tablo 1. Kardiyoloji hekimlerinin iskemik KAH tanı ve takibinde kullandkkları testlerle ilgili sorulara verdikleri yanitlar.

Bulunduğunuz hastane içinde așağıdakilerden hangisi
yapılabilmektedir?

EKG ve Eforlu EKG

Biyokimya

Akciğer Grafisi

Rest EKO

Invaziv koroner anjiografi (KAG)

MPS SPECT ve GATED

iskemik KAH șüphesi ile gelen stabil tipik/atipik anginalı bir hastada en sık istediğiniz 5 tetkik nelerdir?

\section{Rest EKG}

Biyokimya

Eforlu EKG

Rest EKO

MPS SPECT

Bilinen KAH takibinde semptomatik ancak stabil bir hastada en sık istediğiniz 5 tetkik nelerdir?

\begin{tabular}{|l|c|c|}
\hline Rest EKG & 25 & 96,2 \\
\hline Biyokimya & 23 & 88,5 \\
\hline Eforlu EKG & 21 & 80,8 \\
\hline Rest EKO & 19 & 73,1 \\
\hline MPS sPECT & 13 & 50,0 \\
\hline $\begin{array}{l}\text { Süpheli iskemik KAH düşündüğünüz bir hastada "test } \\
\text { öncesi olasılığı" nasıl belirliyorsunuz? }\end{array}$ & $n$ & $\%$ \\
\hline Anamnez+FM+bivokimya+ rest EKG ile & 21 & 80,8 \\
\hline Yaș, cinsiyet ve anjina tipi ile & 19 & 73,1 \\
\hline Eforlu EKG ile & 17 & 65,4 \\
\hline MPs ile & 14 & 53,8 \\
\hline Kalsiyum skorlama ile & 2 & 7,7 \\
\hline KAH'ta stresle tetiklenen (stress-induced) iskemi & & \\
\hline $\begin{array}{l}\text { kanıtı için günlük pratiğinizde en ç0k hangi iki testi } \\
\text { kullanıyorsunuz? }\end{array}$ & $n$ & $\%$ \\
\hline Eforlu EKG & 16 & 65,4 \\
\hline Stres MPS sPECT ve GATED & 4 & 15,4 \\
\hline Koroner anjiyografi (KAG) & & 100,0 \\
\hline
\end{tabular}


Tablo 2. MPS'nin tercih edilen endikasyonları ve şüpheli iskemik KAH'ta test öncesi olasıllklara göre kullanım..

\begin{tabular}{|c|c|c|}
\hline $\begin{array}{l}\text { MPS'yi en çok hangi üç endikasyon için tercih } \\
\text { ediyorsunuz? }\end{array}$ & n & $\%$ \\
\hline Şüpheli iskemik KAH vakalarında tanı amaçlı & 22 & 84,6 \\
\hline $\begin{array}{l}\text { Koroner anjiyoda ya da BT-anjiyo'da bulunan bir } \\
\text { lezyonun klinik önemini belirlemek için }\end{array}$ & 14 & 53,8 \\
\hline $\begin{array}{l}\text { Bilinen КАН hastalarında semptomatik hastalığın } \\
\text { takibinde }\end{array}$ & 12 & 46,2 \\
\hline Canlılık (viabilite) tayini için & 10 & 38,5 \\
\hline $\begin{array}{l}\text { Diğer (Yetersiz efor testi, sol dal bloğu vb.. } \\
\text { varlığında) }\end{array}$ & 8 & 30,8 \\
\hline $\begin{array}{l}\text { Şüpheli iskemik KAH düssündüğüüüz hastalarda } \\
\text { MPS'yi en çok hangi “test öncesi olasılık”lar için } \\
\text { kullanıyorsunuz? }\end{array}$ & $\mathrm{n}$ & $\%$ \\
\hline $\begin{array}{l}\text { Test öncesi olasılığı ne olursa olsun efor yapamayan } \\
\text { ve rest EKG'si değerlendirilemeyen semptomatik } \\
\text { hastalarda }\end{array}$ & 23 & 88,5 \\
\hline $\begin{array}{l}\text { Orta olasılıklı semptomatik hastalarda seçilecek } \\
\text { tedaviyi ve prognozu belirlemek için }\end{array}$ & 12 & 46,2 \\
\hline $\begin{array}{l}\text { Düşük olasılıklı semptomatik hastalarda göğüs } \\
\text { ağrısının kardiyak kökenli olup olmadığını ayırt } \\
\text { etmek ve iskemi varlığını değerlendirmek için. }\end{array}$ & 9 & 34,6 \\
\hline $\begin{array}{l}\text { Yüksek riskli asemptomatik hastalarda hastanın } \\
\text { prognozunu belirlemek için. }\end{array}$ & 6 & 23,1 \\
\hline $\begin{array}{l}\text { Test öncesi olasılı̆̆ı ne olursa olsun semptomatik ve } \\
\text { efor yapabilen hastalarda }\end{array}$ & 5 & 19,2 \\
\hline $\begin{array}{l}\text { Yüksek olasılıklı semptomatik hastalarda seçilecek } \\
\text { tedaviyi ve prognozu belirlemek için. }\end{array}$ & 4 & 15,4 \\
\hline
\end{tabular}

"MPS'yi en çok hangi üç endikasyon için tercih ediyorsunuz?" sorusuna birinci sırada verilen cevap \%84,6 ile "Şüpheli iskemik KAH vakalarında tanı amaçlı" șeklindedir. "KAG' de ya da bilgisayarlı tomografi ile anjiyo (BT-anjiyo)'da bulunan bir lezyonun klinik önemini belirlemek için" ve "Bilinen $\mathrm{KAH}$ hastalarında semptomatik hastalığın takibinde" de sırasıyla $\% 53,8$ ve $\% 46,2$ oranında MPS istemi yapıldığı görülmektedir. Viabilite tayini ile yetersiz efor testi, sol dal bloğu vb EKG değerlendirme zorlukları olması durumlarında MPS, \%30'un üzerinde klinisyen için ilk üç endikasyon arasında yer almıştır. "Şüpheli iskemik KAH düșündügüüüz hastalarda MPS'yi en çok hangi test öncesi olasılıklar için kullanıyorsunuz?" sorusuna ise katılımcıların \%88,5'i "Test öncesi olasılığı ne olursa olsun efor yapamayan ve istirahat EKG'si değerlendirilemeyen semptomatik hastalarda" şeklinde cevap vermiștir. "Orta olasılıklı semptomatik hastalarda seçilecek tedaviyi ve prognozu belirlemek için" MPS'nin tercih edilme oranı \%46,2 ve "Düșük olasılıklı semptomatik hastalarda göğüs ağrısının kardiyak kökenli olup olmadığını ayırt etmek ve iskemi varlığını değerlendirmek için" tercih edilme oranı ise \%34,6 olarak saptanmıștır (Tablo 2).

Kardiyoloji hekimlerinin yarısı farmakolojik veya eforlu stres tipinin seçimini belirterek istem formuna yazdığını, \%23,1’i nadiren yazdığını ve \%11,5’i hiçbir zaman yazmadığını ifade etmektedir. Hastaya göre stres tipini tercih edenler $\%$ 73,1 ile birinci sırada yer alırken, ikinci sırada eforlu strese daha çok güvendiği için genellikle efor testini tercih edenler $(\% 23,1)$ yer almıștır. Farmakolojik strese daha çok güvenenler ise \%3,8'de kalmıștır. Katılımcıların \%50'si MPS'de stres tipine, klinisyen ve nükleer tıp hekiminin birlikte karar vermesi gerektiğini, \%38,5’i kardiyoloji hekiminin, geriye kalan kısmı ise nükleer tıp hekiminin karar vermesi gerektiğini ifade etmektedir (Tablo 3).

Tıbbi kötü uygulama (malpractice) ile ortaya çıkabilecek olası sorunlarla ilgili olarak stres tipi kararının ve sorumluluğun kime ait olacağına ait görüșler sorulduğunda, katılımcıların \%38,5'i "Stres seçimi hekimlerin ortak kararı ile olmalıdır ve sorumluluk da paylaşılmalıdır" derken; \%30,8'i "Stres seçimi hekimlerin ortak kararı ile olmalıdır, ancak sorumluluk uygulamayı gerçekleștirenindir. Uygulamacı uyguladığı ișlemin sorumluluğundan hiçbir șekilde kurtulamaz." biçiminde görüș bildirmiştir. \%11,5 oranında katılımcı kararın ve sorumluluğun kardiyoloğa ait, \%7,7'si ise kararın ve sorumluluğun nükleer tıp hekimine ait olduğunu savunmuștur. \%3,8'lik bir katılımcı ise kararın ve sorumluluğun hastaya ait olduğunu düşünmektedir (Tablo 4).

Katılımcıların geçmişteki tecrübelerine göre MPS rapor yorumlarına ait en olumlu ve en olumsuz üçer geri bildirim vermeleri istendiğinde; olumlu geri bildirimler için doğru pozitif sonuçlar $(\% 65,4)$ ve doğru negatif sonuçlar $(\% 61,5)$ ilk iki sırayı almıștır. Üçüncü sırada raporların standart ve yeterli olması $(\% 38,5)$ yer almıştır. Olumsuz geri bildirimler için yapılan değerlendirmede ise katılımcıların \%76,9'u tetkikin uzun sürmesini, \%50'si geç randevu verilmesini ve \%42,3'ü yanlış negatif sonuçları vurgulamıștır (Tablo 5).

Kardiyoloji hekimleri, MPS raporu eline ulaștığında \%65,4 oranında rapordaki tüm teknik ayrıntıları dikkatle okuduğunu ve hastaya ve stres yöntemine dair detayların raporda yer almasını beklediğini ifade etmiștir. Ancak \%53,8'i raporun sadece sonucunu okumaya vakti olduğunu, önemli bilgilerin kısa olarak yazılmasını beklediğini belirmiştir. \%34,6 lık bir kesim ise rapor ekindeki görüntüleri de inceleyerek gerekirse ek yorum ve düzeltmeler istediğini bildirmiștir (Tablo 6). 
Tablo 3. Hangi stres tipinin tercih edildiğil, istem kağıdına hangi sıklıkta yazıldığı ve hangi hekim tarafindan stres tipine karar verilmesine ait kanaatlerin orant.

\begin{tabular}{|l|c|c|}
\hline $\begin{array}{l}\text { MPS için stres tipi (farmakolojik, eforlu vs) seçimi } \\
\text { yapıyor ve istem formunda yazıyor musunuz? }\end{array}$ & n & $\%$ \\
\hline Evet, her zaman & 13 & 50,0 \\
\hline Nadiren & 6 & 23,1 \\
\hline Hayır, hiçbir zaman & 3 & 11,5 \\
\hline Hangi stres tipini tercih ediyorsunuz? & & \\
\hline $\begin{array}{l}\text { Hastaya göre değișir (Efor yapabilenlerde eforlu, } \\
\text { yapamayanlarda farmakolojik stres) }\end{array}$ & 19 & 73,1 \\
\hline $\begin{array}{l}\text { Genellikle efor testi (eforlu strese daha ç0k } \\
\text { güveniyorum) }\end{array}$ & 6 & 23,1 \\
\hline $\begin{array}{l}\text { Genellikle farmakolojik stres (farmakolojik strese } \\
\text { daha çok güveniyorum) }\end{array}$ & 1 & 3,8 \\
\hline
\end{tabular}

MPS'de stres tipine kimin karar vermesi gerektiğine inaniyorsunuz?

Klinisyen ve nükleer tıp hekiminin birlikte

Tetkik istemini yapan klinisyen hekimin (Kardiyoloğun)

Tetkiki uygulayacak olan nükleer tıp hekiminin

Tablo 4. Thbi kötü uygulama açısından stres kararı verme ve sorumluklarma ait görẗşler

Malpractice" yasası açısından ele alındığında, MPS tipine karar vermede çıan sorunlar açısından en fazla aşağıdaki hangi yoruma katılırsınız?

n $\quad \%$

Stres seçimi hekimlerin ortak kararı ile olmalıdır. Sorumluluk da paylașılmalıdır.

Stres seçimi hekimlerin ortak kararı ile olmalıdır. Ancak sorumluluk uygulamayı gerçekleștirenindir. Uygulamacı uyguladığı ișlemin sorumluluğundan hiçbir șekilde kurtulamaz

Stres seçimine klinisyen hekim (tetkiki isteyen hekim) karar vermelidir. Sorumluluk da klinisyenindir.

Stres seçimi nükleer tıp hekiminin ya da laboratuarda stres uygulamasını yapacak hekimin iși ve sorumluluğu olmalıdır. Klinisyenin yasal sorumluluğu yoktur

Hekimler her tür uyumsuzluk halinde mutlaka ortak bir değerlendirme ile birbirlerini bilgilendirmeli, ulașılamaması/ uyumsuzluğun devam etmesi halinde karar hastaya bırakılmalıdır. Sorumluluk da hasta ile birlikte hastanın kararını paylaşan hekimindir

Stres seçimi tamamen hastaya bırakılmalıdır. Sorumluluk da hastanın olmalıdır.

$1 \quad 3,8$

\section{TARTIȘMA}

Kardiyoloji hekimlerinin çalıștıkları hastanede noninvaziv kardiyolojik tanı yöntemlerinden EKG, eforlu EKG ve biyokimya gibi tetkiklere tam olarak ulaşabildiği, rest EKO, MPS SPECT ve GATED SPECT gibi tetkiklere ise \%50'nin üzerinde bir oranla ulaşabildikleri görülmektedir. Hem iskemik $\mathrm{KAH}$ şüphesi ile gelen stabil tipik/atipik anginalı hastalarda hem de bilinen $\mathrm{KAH}$ takibinde semptomatik ancak stabil hastalarda MPS, istirahat EKG, biyokimya, eforlu EKG ve istirahat EKO tetkiklerinin ardından $\% 50$ ve üzerinde istenmektedir. Bu veriye, MPS istemlerine yapılan olumlu geri bildirimlerde ilk sırada yüksek doğruluk oranlarının bulunmasının önemli katkısı olduğu değerlendirilmektedir. Şüpheli iskemik KAH düșünülen bir hastada "test öncesi olasılı̆̆ın" belirlenmesinde; anamnez, fizik muayene, demografik özellikler ve eforlu EKG'nin ardından \%50'nin üzerinde bir oranla MPS tercih edilmektedir. Bu durum kardiyoloji hekimlerinin invaziv KAG öncesinde eforlu EKG ve MPS ile önemli oranda iskemi kanıtı araştırdıklarını göstermektedir. Eforlu EKG'nin yüksek oranda kullanılmasının, MPS'nin doğruluk değerlerine katkı verdiği anlașılmaktadır. Stres EKG'nin ucuz olması ve yaygın kullanımına rağmen düșük doğruluk düzeyi, iskemi bölgesini ve şiddetini gösterememesi ve özellikle yașlı ve kadın hastalarda düşük egzersiz kapasitesine bağlı olarak hiç gerçekleștirilememesi önemli dezavantajlardır. MPS ise sol sirkumfleks arter dahil olmak üzere özellikle tek damar hastalıklarında yüksek duyarlılığa sahiptir ve perfüzyon ve fonksiyonel değerlendirmeyi objektif şekilde gösterebilir. Gerektiğinde farmakolojik stres olanağı da sağlar (3).

Klinisyenler, MPS'yi en çok iskemik KAH șüphelendikleri hastalarda tanı amaçlı olarak kullandıklarını ifade etmektedirler (\%84,6). Bu grubun yanıtları ile birinci soruda șüpheli hastalık ile gelenler için MPS'yi ilk tercihe yazanlar kendi arasında çapraz olarak değerlendirildiğinde ( $n=22), \% 76,9^{\prime} u$ arasında uyum bulunmaktadır (Her iki durumda da MPS'ye öncelik verenler). İnvaziv KAG'nin öncelikli tercih oranı \%27'de kalmıștır. Bu durum hasta seçiminde eleyici bir öncü test olarak MPS'nin doğrudan invaziv KAG'ye göre yüksek revaskülarizasyon oranlarının azaltılması yönünden literatür bilgisi ile uyumludur (4). Öte yandan MPS kullanımında daha önceden saptanan koroner lezyonun klinik önemini belirlemek için yapılan istem \%54 ile ikinci sıradadır. Bu \%54'lük grup ( $n=14)$ bilinen KAH takibinde en sık istenilen beș tetkik ile çapraz değerlendirmeye alındığında, MPS'yi \%64 oranında tercih ettikleri görülmüștür. KAG ise \%50 oranında tercih edilmiștir. Bu veriler Avrupa Kardiyoloji Derneğinin (ESC) 2013 ve 2019 kararlı KAH kılavuzları ile uyumlu olarak klinik șüphenin önem kazandığı düșünülen hastalarda, MPS'nin, KAG'ye göre öncelikle değerlendirildiğini gösterebilir $(5,6)$. MPS'nin bilinen KAH hastalarında semptomatik KAH takibinde kullanımı \%50'nin altındadır, bu durum biyokimya, efor testi ve EKO' nun bu amaç için öncelikle kullanıldığına ișaret edebilir (7). 
Tablo 5. MPS raporlarma ait olumlu ve olumsuz geri bildirimler.

\begin{tabular}{|c|c|c|}
\hline $\begin{array}{l}\text { MPS istemlerinizden bugüne dek edindiğiniz en olumlu } 3 \text { geri } \\
\text { bildirim hangileridir? }\end{array}$ & n & $\%$ \\
\hline Doğru pozitif sonuçlar (yüksek sensitivite) & 17 & 65,4 \\
\hline Doğru negatif sonuçlar (yüksek spesifisite) & 16 & 61,5 \\
\hline $\begin{array}{l}\text { Raporlarda ve rapor eklerinde tam ve doğru bilgilendirme } \\
\text { açısından verilerin yeterli olması (Raporlarda standardizasyon) }\end{array}$ & 10 & 38,5 \\
\hline $\begin{array}{l}\text { MPS istemlerinizden bugüne dek edindiğiniz en olumsuz } 3 \text { geri } \\
\text { bildirim hangileridir? (Yanına 1,2,3 șeklinde yazınız). }\end{array}$ & n & $\%$ \\
\hline Tetkikin uzun sürmesi. & 20 & 76,9 \\
\hline Geç randevu verilmesi & 13 & 50,0 \\
\hline Yanlıș negatif sonuçlar (düșük spesifisite) & 11 & 42,3 \\
\hline
\end{tabular}

Tablo 6. Kardiyoloji hekimlerinin MPS raporundan beklentileri.

MPS raporları elinize ulaștığında rutinde en çok nelere dikkat edersiniz? (En çok 2 seçenek ișaretleyiniz). n $\quad \%$

Rapordaki sonucun geçerliliğini ve etkinliğini efor süresi vb gibi teknik ayrıntılar belirlediğinden, bu ayrıntıları dikkatle okurum. Bu nedenle sonuçla birlikte teknik bilgilerin (hasta semptomları, elde edilen EKG'si, boyu, kilosu, TA, efor / farmakolojik ajan tipi, ișlem süresi, verilen dozlar, iskemi șiddeti vs) raporda ayrıntılı yer almasını beklerim.

Raporun sadece sonucunu okuyabilecek vaktim oluyor. 0 nedenle sonuç kısa ve açık olmalı. Tedavi kararını etkileyecek bilgiler kısaca ve net olarak vurgulanmalıdır

$14 \quad 53,8$

Raporla birlikte verilen görüntüleri de incelerim. Görüntülere göre gerekirse sonuç ile ilgili ek yorum veya revizyon isterim

Diğer

Klinisyenin şüpheli iskemik KAH düșündüğü hastalarda MPS'yi en çok "test öncesi olasıllı̆ı ne olursa olsun efor yapamayan ve rest EKG'si değerlendirilemeyen semptomatik hastalarda" kullanması stres EKG'nin yeterli bilgi veremediği veya uygulanamadığı hasta grupları için uygun bir yaklașım tarzıdır. Benzer şekilde orta olasılıklı semptomatik hastalarda seçilecek tedaviyi ve prognozu belirlemek için MPS'nin yarıya yakın oranda tercih edilmesi de invaziv KAG'nin iskemiyi ve stenozun klinik önemini saptayamadığı durumlar nedeniyle doğru bir değerlendirmedir. Üçte birden daha fazla katılımcının düşük olasılıklı semptomatik hastalarda gögüs ağrısının kardiyak kökenli olup olmadığını ayırt etmek ve iskemi varIığını değerlendirmek için MPS'yi kullanması; stres MPS'den beklenen faydanın pozitif öngörü değerinin orta ve yüksek olasılıklı semptomatik hasta grubunda yüksek olması nedeni ile yüksek bir rakam olarak değerlendirilmiștir (7).

Klinisyenlerin ESC'nin 2013 ve 2019 kararlı KAH kılavuzlarına ve uygunluk kriterlerine bağlı kaldıkları ve invaziv KAG öncesinde iskemi kanıtı belirlemek üzere MPS'den yararlandıkları anlașılmaktadır. Aslında her iki ESC kılavuzu da stres EKO, kardiyak manyetik rezonans ve fraksiyone akım rezervi gibi diğer bașka tetkiklerin de kullanılmasıyla ilgili belirli durumlar önermektedir, ancak klinisyenlerin bu tetkiklere ulasamadıkları ya da muhtemelen ekonomik ve zamansal nedenlerle tercih etmedikleri anlaşılmaktadır (4). Bu durumda ilimizde MPS'nin, invaziv KAG yapılması öncesinde iskemi kanıtı elde edilmesi için önemli bir tetkik olarak kullanıldığı anlaşılmaktadır. Öte yandan, tetkikin olumsuzlukları arasında, uzun sürmesi ve geç randevu verilmesine vurgu yapılması, ilimizde sadece devlet hastanesinde MPS yapılan bir nükleer tıp ünitesi olması ve tek klinik üzerindeki yükün fazlalığı ile ilgili olabilir. Kardiyoloji hekimlerinin MPS'yi uygun endikasyonları ile kullanma çabası içerisinde olmalarına rağmen, üçte bir civarında klinisyenin nükleer kardiyolojik tetkiklere ulaşamaması durumu, kararlı KAH tanı ve tedavisinin takibi açısından bir olumsuzluk olușturabilir (7). Ayrıca bu durum, ildeki tıp fakültesinin nükleer tıp kliniğine gamma kamera kurulumunun gerekliliğini gösteriyor olabilir.

Hastaların efor kapasitelerinin bireysel değişiklikler göstermesi eforlu veya farmakolojik stresten birinin seçilmesini zorunlu kılmaktadır. Bu seçim hastanın ilk muayenesini yapmakla yükümlü olan kardiyoloji hekimi tarafından veya MPS ișlemini uygulayan nükleer tıp uzmanı tarafından yapılabilir. Buna paralel biçimde her zaman veya sıklıkla istem kağıdına stres seçimi yazanların oranı \%60'a, hastaya göre stres tipini tercih edenlerin oranı \%75'e ve stres tipini seçme kararına nükleer tıp hekiminin de dahil olması gerektiğini düșünenlerin oranı \%50'ye yakın bulunmuştur. Tıbbi kötü uygulama ile ilgili olası sorunlar açısından; uygulamada değilse de kararın verilmesinde tarafların sorumlu olacağı göz önünde bulundurulduğunda, karșılıklı diyaloğun önemi ortaya çıkmaktadır. Genellikle yapılan stres tipi tercihi efor lehine altı kat fazladır. Bunun nedeni muhtemelen eforlu EKG nedeni ile kardiyoloji hekimlerinin efora karşı daha așina ve bilgili olmaları ve efora kardiyak yanıtın prognozu belirlemede daha etkili olduğunun düşünülmesidir. Yine de hastaya göre tercih yapanların en yüksek sayıda olması $(\% 73,1)$ kişiye özel yaklaşımların benimsendiğini göstermektedir $(8,9)$.

Tıbbi kötü uygulamalar ile ilgili yasa açısından MPS'de stres seçimi ve olası sorumluluğun kime ait olacağı önemli bir konudur. Aslında tıbbi kötü uygulamaya ilișkin ayrı bir yasa bulunmamaktadır. 1219 nolu 1928 tarihli "Tababet ve Şuabatı San'atlarının Tarzı İcrasına Dair Kanun”un Ek 12'nci maddesi uyarınca yapılan "Tıbbi Kötü Uygulamaya Ilișkin Zorunlu Mali Sorumluluk Sigortası”nın uygulanmasına ilişkin esasla- 
rın belirlendiği "Tıbbi Kötü Uygulamaya İlișkin Zorunlu Mali Sorumluluk Sigortası Tarife ve Talimatı" mevcuttur. (Talimat 27648 sayılı Resmî Gazetede 21/07/2010 tarihinde yayımlanmıștır). Söz konusu talimatın hekimlere yüklediği sorumluluk 11/1/2011 tarihli 6098 nolu Türk Borçlar Kanunun 506. maddesindeki-"Vekil, üstlendiği iş ve hizmetleri, vekâlet verenin haklı menfaatlerini gözeterek, sadakat ve özenle yürütmekle yükümlüdür. Vekilin özen borcundan doğan sorumluluğunun belirlenmesinde, benzer alanda iş ve hizmetleri üstlenen basiretli bir vekilin göstermesi gereken davranış esas alınır." ibaresine dayanır. Buna göre hekim ve hasta arasında ise hasta doğrudan hekime başvurduğunda ve hekim tarafından tedavi sözü verildiğinde veya tedaviye başlandığında aralarında bir "sözleșme" ilișkisi kurulmuș olur. Sözleșme sonucu hekim verdiği hizmeti en güzel șekilde yapmakla sorumludur $(10,11)$. Kardiyolog ve nükleer tıp uzmanının gereken noktalarda iş birliği yaparak karar ve sorumluğa ortak olmaları sorumluluğun ifası açısından önemlidir. Kardiyoloji hekimlerinin \%40'a yakınının MPS'nde stres seçimi kararından açığa çıkan sorunlara ait "Hekimlerin ortak kararı ile olmalıdır ve sorumluluk da paylaşılmalıdır" demeleri bu açıdan anlamlıdır. \%30 civarında kardiyoloji hekimi "Stres seçimi hekimlerin ortak kararı ile olmalıdır, ancak sorumluluk uygulamayı gerçekleștirenindir, uygulamacı uyguladı̆̆ı işlemin sorumluluğundan hiçbir șekilde kurtulamaz." șeklinde görüș beyan etmiștir. İlgili talimata göre, önermenin ikinci yarısı gerçekçi olmakla birlikte, karara katılan kardiyoloji hekiminin de sorumluluktan kurtulmasının mümkün olmadığı anlașılmaktadır. \%5'in altındaki klinisyen ise, kararın ve sorumluluğun hastaya ait olması gerektiğini düşünmektedir. Ancak hasta bu alanda bilgisizliği ve yetersizliği nedeni ile doktora vekalet vermiștir. Dolayısıyla aynı talimata göre, hastanın doğru kararı verecek donanıma sahip olmadığı ve kararı bir hekim ile birlikte vermesinin gerektiği değerlendirilmektedir. Bu sorunlar tümüyle olmasa bile büyük ölçüde hasta ile birlikte değerlendirilip hem stres tipi hem de MPS yapılmasıyla ilgili olarak bilgilendirilmiş onam alınmasıyla çözülebilir.

Değişen oranlarda olmak üzere tüm hekimler MPS rapor yorumlarına ait en olumlu ve en olumsuz üçer geri bildirimin içinde birbirine zıt noktaları bildirmiștir. Üçte iki hekim doğru pozitif sonuçlardan memnun iken bește bir civarında hekim yanlıș pozitif sonuç bildirmiștir. Doğru negatif sonuç bildirenlerin oranı yanlış negatif sonuç bildirenlerin 1,5 katı çıkmıştır. Üçüncü sırada \%40'a yakın hekim raporlarda standardizasyondan memnun iken tersine \%10'a yakın hekim raporları yetersiz bulmuştur. MPS raporlarının yetersiz olduğunu düșünenlerin oranı, ülkemizde raporlarda standardizasyonu sağlamak amacı ile yazılan kılavuzlardaki öneriler uygulanarak azaltılabilir (12). Olumsuz geri bildirimlere göre ilk üç sırayı tetkikin uzun sürmesi, geç randevu verilmesi ve yanlış negatif sonuçlar almıștır. Bunlara göre nükleer tıp raporlarından genellikle tıbbı anlamda bir memnuniyet mev- cuttur. Nükleer tıp hizmetinin yapısından kaynaklanan tetkik ve randevu süresi ile ilgili olumsuzluklar ise öne çıkmaktadır. Yukarıda da ifade edilen şehrimizde üniversite hastanemizde gama kamera kurulumu ile ilgili gerekliliğin diğer bir yönden de vurgulandı̆̆ı söylenebilir.

Kardiyoloji hekimlerinin üçte ikisi MPS raporu eline ulaştığında rapordaki tüm teknik ayrıntıları dikkatle okuduğunu ve bu detayların raporda olmasını beklediğini belirtirken, yaklaşık yarısı ise sadece sonucunu okumaya vakti olduğunu önemli bilgilerin kısa olarak yazılmasını beklediğini belirtmektedir. Bu durum; genel olarak rapor içeriğinde ayrıntılı bilgilerin yazılmasının talep edildiği ve uygun zaman bulunabildiği koşullarda okunacağı, kısıtlı zamanlarda ise sonuç kısmının en önemli bilgileri içerecek kadar kısa ve açık yazılması gerektiği șeklinde değerlendirilmiștir. Üçte birden fazla hekimin rapor ekindeki görüntüleri de inceleyerek gerekirse ek yorum ve düzeltmeler de istediğini bildirmesi hem raporun ayrıntılı olarak okunduğunu hem de nükleer tıp hekimi ile iletişimin iyi düzeyde olduğunu göstermesi açısından olumlu olarak değerlendirilmiștir.

\section{SONUC}

Sonuç olarak ilimizde iskemik KAH tanı ve takibinde MPS, yüksek duyarlık ve özgüllük oranlarıyla tercih edilen bir tetkiktir. Kardiyoloji hekimlerinin iskemi kanıtı için MPS'yi kullanma tercihlerine rağmen ulaşılabilirlik sorunu olduğu anlaşılmaktadır. Bu durumun, MPS yerine daha az etkin ve pahalı yöntemlerin kullanılmasına yol açma potansiyeli olușturduğu değerlendirilmektedir. İnvaziv KAG'nin uygunsuz ve yaygın kullanımının oluşturabileceği sağlık ve ekonomi alanındaki kayıpların, ancak MPS'nin kullanımı ile önlenebileceği göz önünde bulundurulduğunda, șehrimizde özellikle de üniversitemizde bir gama kamera ihtiyacı olduğu görülmektedir. Öte yandan, nükleer tıp görüntüleme yöntemlerinin kararlı iskemik KAH tanı ve takibinde kullanım yaygınlığının ve etkinliğinin optimal düzeye çıkması, karar ve sorumluluk paylașımları, disiplinler arası iletișim kanallarının arttırılmasıyla sağlanabilir.

\section{BILDIRIMLER}

Değerlendirme

Iç ve dıș danıșmanlık

Çıkar Çatıșması

Yazarlar bu makale ile ilgili herhangi bir çıkar çatışması bildirmemișlerdir.

Finansal Destek

Yazarlar bu makale ile ilgili herhangi bir malî destek kullanımı bildirmemişlerdir.

Etik Beyan

Bu çalıșma için Kahramanmaraş Sütçü İmam Üniversitesi Tıp Fakültesi Klinik Araștırmalar Etik Kurulundan 18.09.2019 tarih ve 2019/17 sayılı yazı ile izin alınmıș olup Helsinki Bildirgesi kriterleri göz önünde bulundurulmuștur. 


\section{Teșekkür}

Çalıșmamıza verdiği destekten dolayı Cengiz Tașçı ve Adem Doğaner'e teșekkür ederiz.

\section{KAYNAKLAR}

1. Canbaz Tosun F., Özdemir S., Şen F., Demir H., Özdemir E., Durmuş Altun G. Myocardial Perfusion SPECT Procedure Guideline. Nuclear Medicine Seminars 2020;6(2):90-134. https://doi.org/10.4274/nts.galenos.2020.0010

2. Ural D. Kardiyologların Nükleer Kardiyolojiden Beklentileri. Nucl Med Semin 2018;4:157-162 https://doi.org/10.4274/ nts.2018.019

3. Taş̧ı C. Türkiye'de ve Dünyada Kararlı Koroner Arter Hastalığı Tanısında Noninvaziv Testlerin ve İnvaziv Koroner Anjiyografinin Kullanımı. Turkiye Klinikleri J Nucl Med-Special Topics 2015;1(3):1-12

4. Taş̧̧ C., Özçelik N. An Overview on Coronary Heart Disease (A Comparative Evaluation of Turkey and Europe) and Costeffectiveness of Diagnostic Strategies. Molecular Imaging and Radionuclide Therapy 2011;20(3): 75-93 https://doi. org/10.4274/MIRT.33

5. Task Force Members, Montalescot G, Sechtem U, Achenbach S, Andreotti F, Arden C, Budaj A et al. 2013 ESC guidelines on the management of stable coronary artery disease: the Task Force on the management of stable coronary artery disease of the European Society of Cardiology. Eur Heart J, 2013;34(38):2949-
3003. https://doi.org/10.1093/eurheartj/eht296.

6. Knuuti J, Wijns W, Saraste A, Capodanno D, Barbato E, FunckBrentano C, et al., 2019 ESC Guidelines for the diagnosis and management of chronic coronary syndromes. Eur Heart J 2019; https://doi.org/10.1093/eurheartj/ehz425.

7. Yapıcı 0. Miyokart Perfüzyon Sintigrafisinde Olgu Seçimi Kriterleri: Bölge Genelinden Sevk Edilen ve Tek Merkezde Raporlanan 990 Olgunun Retrospektif Analizi.Turk J Nucl Med 2010;19(3):110-7

8. Henzlova MJ., Duvall WL., Einstein AJ.,Travin MI., Verberne HJ: ASNC imaging guidelines for SPECT nuclear cardiology procedures: Stress, protocols, and tracers. I Nucl Cardiol 2016;23:606-39. https://doi.org/10.1007/s12350-015-0387-x

9. Taşçı C., Ak C. Kararlı Koroner Arter Hastalığında Tedavi Stratejileri Kılavuzluğunda Tanı Stratejilerinin Maliyet Etkinliği: "Bir Öncü-eleyici Test Olarak Miyokard Perfüzyon Sintigrafisi". İstanbul Med J 2014; 15: 145-53 https://doi. org/10.5152/imj.2014.64426

10. https://www.resmigazete.gov.tr/eskiler/2011/02/20110204-1. htm (son erișim tarihi: 06.02.2021)

11. https://www.resmigazete.gov.tr/ eskiler/2010/07/20100721-17-1.htm (son erișim: 06.02.2021)

12. Canbaz Tosun F., Demir H., Tașçı C., Özdemir E., Özdemir S., Şen F., Durmuş Altun G. Nucl Med. Miyokart Perfüzyon SPECT GörüntülemedeYapılandırılmış Raporlama. Semin 2020;6:135170. https://doi.org/10.4274/nts.galenos.2020.0011 


\section{Ek 1. Kardiyologlar için Anket Formu}

1- İskemik KAH șüphesi ile gelen stabil tipik/atipik anginalı bir hastada en sık istediğiniz 5 tetkik hangisidir?
a) Rest EKG
h) BT-anjiyo
0) Fraksiyone akım rezervi (FAR)
b) Biyokimya
i) MR-anjiy0
p) IVUS
c) Eforlu EKG
j) Kalsiyum skorlaması
r) Diğer......
d) Rest Eko
k) PET perfüzyon
e) Stres Eko
I) İnvaziv Koroner Anjiyo (KAG)
f) MPS SPECT
m) Akciğer grafisi
g) MPS Gated SPECT
n) Bașka bir branștan konsültasyon

2- Bilinen KAH takibinde semptomatik ancak stabil bir hastada en sık istediğiniz 5 tetkik așağıdakilerden hangisidir?
a) Rest EKG
h) BT-anjiyo
0) FAR
b) Biyokimya
i) MR-anjiyo
p) IVUS
c) Eforlu EKG
j) Kalsiyum skorlaması
r) Diğger...
d) Rest Eko
k) PET perfüzyon
e) Stres Eko
I) Invaziv Koroner Anjiyo
f) MPS SPECT
m) Akciğer grafisi
g) MPS Gated SPECT
n) Bașka bir branștan konsültasyon

3- Bulunduğunuz hastane icinde așağıdakilerden hangisi yapılabilmektedir?
a) EKG ve Eforlu EKG
h) BT-anjiyo
0) FAR
b) Biyokimya
i) MR-anjiyo
p) IVUS
c) Akciğer grafisi
j) Kalsiyum skorlaması
r) $0 \mathrm{KT}$
d) Rest Eko
k) PET perfüzyon
s) Hepsi
e) Stres Eko
I) Invaziv Koroner Anjiyo (KAG)
s) Diğer...
f) MPS SPECT
m) PKG uygulamaları
g) MPS Gated SPECT
n) Koroner By-pass (KABG)

4- Süpheli iskemik KAH düșündüğünüz bir hastada "test öncesi olasılı̆̆ı"nasıl belirliyorsunuz?

a) Hasta anamnezi + FM + Biyokimya + rest EKG ile

b) Yaș-cinsiyet ve anjina tipine bakarak

c) Eforlu EKG ile

d) Stress Eko ile

e) Miyokard perfüzyon sintigrafisiyle

f) Kalsiyum skorlama ile

g) BT-anjiyo ile

h) Kardiyak MR ile

i) Tamamen klinik tecrübeme dayanarak (Sans klinik ile)

j) Framingham skorunu ölçerek.

k) TEKHARF önerilerine dayalı ve toplumumuza özgü bașka bir skorlamayı kullanarak

I) TKD.org sitesindeki risk hesaplamasına bakarak.

m) Diğer 
5- KAH’ta stresle tetiklenen (stress-induced) iskemi kanıtı için günlük pratiğinizde en cok hangi iki testi kullanıyorsunuz. Yanına 1,2 șeklinde yazınız.

\begin{tabular}{|c|c|c|}
\hline a) Eforlu EKG & e) Koroner anjiyo (KAG) & I) Fraksiyone akım rezervi (FAR) \\
\hline b) Stress Eko & f) BT anjïyo & i) Diğer..... \\
\hline c) Stress MPS SPECT & g)Kardiyak MRI & \\
\hline d) Stres MPS Gated SPECT & h)PET perfüzyon & \\
\hline
\end{tabular}

6- MPS'yi en çok hangi üç endikasyon için tercih ediyorsunuz? Yanına 1, 2, 3 șeklinde tercih sıranızı yazınız.

a) Şüpheli iskemik KAH vakalarında tanı amaçlı

b) Bilinen KAH hastalarında semptomatik hastalığın takibinde

c) Koroner anjiyoda ya da BT-anjiyo'da bulunan bir lezyonun klinik önemini belirlemek için

d) Olası revaskülarizasyon sonuçlarını ve prognozu öngörmede

e) Tedavi (revaskülarizasyon/medikal tedavi) sonrası tedavi etkinliğinin belirlenmesinde

f) Canlılık (viabilite) tayini için

g) Nonkardiyak cerrahi öncesi kardiyak risk belirlemede

h) Diğer .......yetersiz efor testi, sol dal bloğu varlığında .....

7- Șüpheli iskemik KAH düșündüğünüz hastalarda MPS’yi en çok hangi “test öncesi olasılık”lar için kullanıyorsunuz? (En çok 3 seçeneği ișaretleyiniz).

a) Yüksek riskli asemptomatik hastalarda hastanın prognozunu belirlemek için.

b) Test öncesi olasılığı ne olursa olsun semptomatik ve efor yapabilen hastalarda

c) Test öncesi olasılığı ne olursa olsun efor yapamayan ve rest EKG'si değerlendirilemeyen semptomatik hastalarda

d) Düșük olasılıklı semptomatik hastalarda göğüs ağrısının kardiyak kökenli olup olmadığını ayırt etmek ve iskemi varlığını değerlendirmek için.

e) Orta olasılıklı semptomatik hastalarda seçilecek tedaviyi ve prognozu belirlemek için

f) Yüksek olasılıklı semptomatik hastalarda seçilecek tedaviyi ve prognozu belirlemek için

8- MPS için stres tipi (farmakolojik, eforlu vs) seçimi yapıyor ve istem formunda yazıyor musunuz?

a) Evet, her zaman

b) Hayır, hiçbir zaman

c) Sıklıkla

d) Nadiren

9- Hangi stres tipini tercih ediyorsunuz?

e) Genellikle efor testi (eforlu strese daha çok güveniyorum)

f) Genellikle farmakolojik stres (farmakolojik strese daha çok güveniyorum)

g) Hastaya göre değișir (Efor yapabilenlerde eforlu, yapamayanlarda farmakolojik stres)

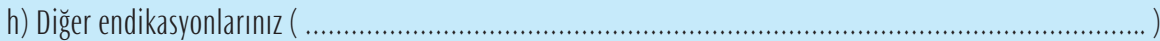

10- MPS'de stres tipine kimin karar vermesi gerektiğine inanıyorsunuz?

a) Tetkik istemini yapan klinisyen hekimin (Kardiyoloğun)

b) Tetkiki uygulayacak olan nükleer tıp hekiminin

c) Klinisyen ve nükleer tıp hekiminin birlikte

d) Hekimlerin önerisi ve etraflıca anlatımıyla hastanın

e) Günümüz koșullarında tamamen hasta ve hasta yakınının isteğine bırakılmalıdır. 
11- Kötü uygulama (malpractice") yasası açısından ele alındığında, MPS tipine karar vermede çıkan sorunlar açısından en fazla așağıdaki hangi yoruma katıılırsınız?

a) Stres seçimine klinisyen hekim (tetkiki isteyen hekim) karar vermelidir. Sorumluluk da klinisyenindir.

b) Stres seçimine klinisyen hekim (tetkiki isteyen hekim) karar vermelidir, ancak sorumluluk testiuygulayan hekimindir.

c) Stres seçimi nükleer tıp hekiminin ya da laboratuarda stres uygulamasını yapacak hekimin iși ve sorumluluğu olmalıdır. Klinisyenin yasal sorumluluğu yoktur.

d) Stres seçimi hekimlerin ortak kararı ile olmalıdır. Sorumluluk da paylașılmalıdır.

e) Stres seçimi hekimlerin ortak kararı ile olmalıdır. Ancak sorumluluk uygulamayı gerçekleștirenindir. Uygulamacı uyguladığı ișlemin sorumluluğundan hiçbir șekilde kurtulamaz.

f) Stres seçimi tamamen hastaya bırakılmalıdır. Sorumluluk da hastanın olmalıdır.

g) Hekimler her tür uyumsuzluk halinde mutlaka ortak bir değerlendirme ile birbirlerini bilgilendirmeli , ulașılamaması / uyumsuzluğun devam etmesi halinde karar hastaya bırakılmalıdır. Sorumluluk da hasta ile birlikte hastanın kararını paylașan hekimindir.

h) Diğer (yazınız)......

12- MPS istemlerinizden bugüne dek edindiğiniz en olumlu 3 geri bildirim hangileridir (Yanına 1,2,3 șeklinde yazınız).
a) Hasta memnuniyeti
b) Doğru pozitif sonuçlar (yüksek sensitivite)
c) Doğru negatif sonuçlar (yüksek spesifisite)
d) Yeterli efor/farmakolojik ajan verilerek tetkikin optimal yapılması.
e) Gereğinde nükleer tıp hekimi ile sonuçları rahatça değerlendirebilme
f) Raporlarda ve rapor eklerinde tam ve doğru bilgilendirme açısından verilerin yeterli olması (Raporlarda standardizasyon)

g) Raporların anlașılması açısından yalınlık ve netlik.

h) Diğer

13- MPS istemlerinizden bugüne dek edindiğiniz en olumsuz 3 geri bildirim hangileridir (Yanına 1,2,3 șeklinde yazınız).
a) Hasta memnuniyetsizliği
b) Tetkikin uzun sürmesi.
c) Geç randevu verilmesi.
d) Yanlış pozitif sonuçlar (düşük sensitivite)
e) Yanlıș negatif sonuçlar (düșük spesifisite)
f) Yeterli efor/farmakolojik ajan verilerek tetkikin optimal yapılamaması.
g) Tetkik için hastaya radyasyon veriliyor olması
h) Gereğinde nükleer tıp hekimi ile sonuçları rahatça değerlendirememe.

i) Raporlarda ve rapor eklerinde tam ve doğru bilgilendirme açısından verilerin eksik olması (Raporlarda standardizasyon eksikliği)

j) Raporlarda karmașık ifadeler (Raporların anlașılma zorluğu)

k) Diğer

14- MPS raporları elinize ulaștığında rutinde en çok nelere dikkat edersiniz. (En çok 2 seçenek ișaretleyiniz).

a) Raporun sadece sonucunu okuyabilecek vaktim oluyor. 0 nedenle sonuç kısa ve açık olmalı. Tedavi kararını etkileyecek bilgiler kısaca ve net olarak vurgulanmalıdır.

b) Raporla birlikte verilen görüntüleri de incelerim. Görüntülere göre gerekirse sonuç ile ilgili ek yorum veya revizyon isterim.

c) Gereği halinde görüntüleri ekrandan değerlendirmek için nükleer tıp kliniğine giderim.

d) Rapordaki sonucun geçerliliğini ve etkinliğini efor süresi vb gibi teknik ayrıntılar belirlediğinden, bu ayrıntıları dikkatle okurum. Bu nedenle sonuçla birlikte teknik bilgilerin (hasta semptomları, elde edilen EKG'si, boyu, kilosu, TA, efor / farmakolojik ajan tipi, ișlem süresi, verilen dozlar, iskemi șiddeti vs) raporda ayrıntılı yer almasını beklerim.

e) Diğer

NOT: Bu anketten elde edilen veriler kimlik bilgisi verilmeden bilimsel sunu ve araștırma içerisinde kullanılacaktır. Katılımınız için teșekkür ederiz. 